\title{
The Flag Bearer of Slovenian Nationalism Knocked Out? The Rise and Fall of the Slovenian National Party
}

\author{
Lucie Chládková \\ Miroslav Mareš
}

\begin{abstract}
This paper analyses the role of the Slovenian National Party (SNS) within the context of Slovenian political system and Slovenian nationalism and national identity. The development of the party is described and its politics is analysed. Special attention is paid to the issue of the so-called "erased" people (citizens from other former republics of Yugoslavia with permanent residence in Slovenia without Slovenian citizenship), which represents an important mobilisation theme of the SNS. The position of the SNS within the Slovenian and international extreme-right spectrum is explained.

Acknowledgement: This paper was written as part of the grant project GAČR GA408/11/0709 "Contemporary Challenges of Democracy in East Central Europe," funded by the Czech Science Foundation.
\end{abstract}

Keywords: Slovenian National Party; SNS; Slovenia; nationalism; right-wing extremism; identity; discrimination.

Tento článok analyzuje úlohu Slovinskej národnej strany (SNS) v rámci slovinského politického systému a slovinského nacionalizmu a národnej identity. Predkladaný článok sa zameriava nielen na vývoj strany ale aj analýzy jej politík. Osobitná pozornost' je venovaná problematike takzvaných „neviditel'ných“ ludí (občanov z iných bývalých republík Juhoslávie s trvalým pobytom v Slovinsku bez slovinského občianstva), čo predstavuje dôležitú mobilizačnú tému pre SNS. Ďalej sa autori zaoberajú aj postojom SNS $v$ rámci slovinského i medzinárodného priestoru $v$ kontexte jeho pravicovej pozície.

Pod'akovanie: Tento článok bol napísaný v rámci grantového projektu GAČR GA 408/11/0709 „Súčasné výzvy demokracie v strednej a východnej Európe“, financovaného Grantovou agentúrou ČR

Kl'účové slová: Slovinská národná strana; SNS; Slovinsko; nacionalizmus; pravicový extrémizmus; identity; diskrimináciu.

\section{Introduction}

Slovenian political spectrum was for a long time characterised by parliamentary representation of the Slovenian National Party (Slovenska Nacionalna Stranka SNS). This party was and is a representative of Slovenian nationalism and a member of the European extreme right party family (Chládková 2014). Continual parliamentary 
presence from 1992 to 2011 was unique in the European context (Jesse and Thieme 2011, 441). However, in the elections in 2011 this party lost its parliamentary status and was not able to win this position again. The aim of this paper is to explain the rise and fall of the SNS in the context of nationalist policy and specifics of Slovenian identity in relation to mobilisation themes of this party. In this context, we will predict the possibilities of future nationalist politics in Slovenia.

\section{Basic theoretical and analytical framework}

Research questions in this paper are based on the theoretical framework elaborated by Uwe Backes who studied several European extreme right parties. He identified some factors related to the success of extreme right parties on the one hand, and those which caused the failure of such parties on the other one. Our goal is to analyse which of these factors have played a role in the case of the Slovenian National Party (up to now, the strongest Slovenian extreme right party in the post-communist history of Slovenia).

Our research questions are:

1. What factors caused the rise of the SNS?

2. What factors caused the decline of the SNS?

3. What potential has the nationalist extreme right in Slovenia?

Backes focused first on the offer profile and then on the opportunity profile of the extreme right parties. Within the offer profile, he defined three factors:

1. Strong charismatic leadership;

2. Effective election campaign organisation;

3. Attractive programme offer (Backes 2012, 164).

Within the opportunity profile, Backes analyzes:

1. Political competitors of the extreme right party (strong center party, strong rightwing populist alternative depolarised party system and strong left-wing populist party);

2. (Un)favourable key events (in the sense of events which can damage the image of the party);

3. Militant democracy (in the sense of institutional and legal measures against extremism);

4. Cordon sanitaire (in the sense of rejection of a coalition with an extremist party);

5. Strong counter-mobilisation (Backes 2012, 166).

If we want to answer the above mentioned research questions related to Backes's 
criteria, we should start with a general introduction to Slovenian politics and nationalism. In this context, we can understand the opportunity profile of the party. Then we will analyze the development, programme and electoral base of the SNS (it means, criteria of the offer profile). The role of the SNS within the extreme right spectrum will also be researched (in relation to the criteria of political competitors).

\section{Slovenian politics and nationalism}

Modern Slovenian nationalism has its roots in the 19th century. The struggle for establishing of Slovenians as a respected European nation was connected with panSlavic ideas as well as with the construction of Slovenians as ancestors of the ancient Carantanian state from the first millennium. This myth plays an important role in Slovenian national identity up to now (Bajt 2011).

The territory of contemporary Slovenia was a part of the Habsburg Austro-Hungarian monarchy. The defeat of Austria-Hungary in the First World War in 1918 opened the door for the creation of the Kingdom of Serbs, Croats and Slovenes. The struggle to annex all historical Carantanian territories to the new state was not successful. After armed conflicts with Italian and Austrian troops, parts of these territories remained in Italy, or in Austria. The national identity of the Slovenian minority in Austria is still supported from Slovenia (Smejkalová 2007).

The Kingdom of Serbs, Croats and Slovenes was renamed to Yugoslavia in 1929 and this step should have demonstrated the unity of southern Slavs. However, Croatian separatism was strong in the 1930s. After the occupation of Yugoslavia by Germany and Italy in 1941, several "puppet states" and dependent territories were established. The Slovenian territory was divided among Germany, Italy, Hungary and the "Croatian state". The Italian part was taken over by Germany in 1943. Collaborators fought in the so-called Slovenian National Guard (Slovensko Domobranstvo) on the side of the Axis powers. They pursued their Slovenian nationalist ideas combined with conservatism, Catholicism and anti-Communism. (Kranjc 2013, 132) Slovenian anti-Fascist partisans were mostly pro-Yugoslavian communists, however, with significant Slovenian patriotic elements. After the end of WW II, the guards were massacred by communist partisans. This issue is still sensitive in Slovenia and its memory policy (Luthar and Luthar 2010) as - among others - the analysis of the SNS politics below shows.

In the post-war era, the personality of the president Josip Broz Tito was an important element of unity of the Socialist Federal Republic of Yugoslavia. After his death, separatist tendencies in several federal republics strengthened, including Slovenia. The most important separatist forces were established within the communist party and its youth organisation. Growing nationalism was in its large part connected with democratic values (Mareš 2011, 363). It was typical also of the short War of Independence in 1991. 
In the independent Slovenia, belonging to the "West" was propagated by a large part of the political spectrum on the one hand, and nationalist and intolerant activities were carried out by the established political forces on the other hand (Bayer 2002, 278). The question of "erased people" (see below) was the most important example (Zorn 2009). In this environment, the rise and fall of the SNS occurred.

\section{Development of the SNS}

The SNS originated from the former Social Democratic Party of Slovenia (the current Slovenian Democratic Party, Slovenska demokratska stranka, SDS), because the founders of the SNS considered the SDSS to be too left-oriented. (Krašovec 2012, 267) Moreover, DEMOS (Democratic Opposition of Slovenia, Demokratična opozicija Slovenije), a coalition of newly founded democratic parties in which the SDSS also participated, was for the SNS not radical enough towards non-Slovenes ${ }^{1}$ living in Slovenia.

The SNS was founded on 17 March 1991 by Zmago Jelinčič, who has been party's leader until today. Due to a rather authoritative style of leadership and Jelinčič's frequent presence in the news, the SNS could be labelled as a party of one man. Jelinčič can veto all decisions made by the presidency of the SNS, he represents the party (even legally), he can convene and lead sessions of all party's bodies, or to designate the secretary general. (SNS 2014a)

The SNS could be categorised as the first genuine Slovenian political party not in a style of Western political parties (not affiliating itself with Christian, liberal or socialdemocratic party families). According to Rizman $(1999,152)$, the SNS served as an incubator for maturing and crystallisation of nationalist, racist and chauvinistic social discourse in Slovenia. For instance, this role of the SNS is clearly demonstrable by the emergence of new far-right political parties which stemmed from the SNS.

The SNS entered the Slovenian Parliament ${ }^{2}$ for the first time in 1992, winning 12 out of 90 seats. From the beginning, the SNS profiled itself as a radical party advocating strict measures against immigrants coming from former Yugoslavia and has continued

1 The term "non-Slovenes" refers to people coming from other republics of exYugoslavia, now living in Slovenia. Non-Slovenes could be also pejoratively called as "čefurji” or "južnjaki” (southerners).

2 The Slovenian parliamentary system is officially bi-cameral, consisting of the National Assembly (the Lower House) and the National Council (the Upper House). Nevertheless, according to experts, the bi-cameral character of the Slovenian Parliament is questionable given the limited power of the National Council and that it is composed of representatives of interest groups. Therefore in this paper we will refer to the National Assembly as the Parliament, meaning only the upper chamber. (Krašovec 2012, 260; Brezovšek et al. 2007, 48). 
to do so ever since. However, just before the national elections in 1992, the SNS faced a possible ban by the court because of the suspicion that the party established its own paramilitary forces. (Krašovec 2012, 268) According to its leader Jelinčič, the SNS had no regular paramilitary forces with any uniforms or formations but that it had 5000 men (meaning members of the SNS) who bought weapons on their own and would be willing to protect Slovenia in the case of an attack.

The results of the SNS in Slovenian general elections are presented in Table 1.

Table 1: Election results of the SNS (Electoral Commission 2014).

\begin{tabular}{|c|c|c|c|c|c|c|c|}
\hline & 1992 & 1996 & 2000 & 2004 & 2008 & 2011 & 2014 \\
\hline & $\begin{array}{l}\% \\
\text { Seats }\end{array}$ & $\begin{array}{l}\% \\
\text { Seats }\end{array}$ & $\begin{array}{l}\% \\
\text { Seats }\end{array}$ & $\begin{array}{l}\% \\
\text { Seats }\end{array}$ & $\begin{array}{l}\% \\
\text { Seats }\end{array}$ & $\begin{array}{l}\% \\
\text { Seats }\end{array}$ & $\begin{array}{l}\% \\
\text { Seats }\end{array}$ \\
\hline SNS & $\begin{array}{l}10.02 \\
12\end{array}$ & $\begin{array}{l}3.22 \\
4\end{array}$ & $\begin{array}{l}4.39 \\
4\end{array}$ & $\begin{array}{l}6.27 \\
6\end{array}$ & $\begin{array}{l}5.4 \\
5\end{array}$ & $\begin{array}{l}1.8 \\
0\end{array}$ & $\begin{array}{l}2.2 \\
0\end{array}$ \\
\hline
\end{tabular}

However, already in summer 1992 first opinion differences among party members emerged. Firstly, some party members accused Zmago Jelinčič of directing the SNS ideologically to the left when Jelinčič advocated the positive role of communist partisans during the Second World War and their fight against Slovenian collaborators. (Kuzmanić 1995) Secondly, another issue was the support of Jelinčič and other MPs from the SNS to the government of Prime Minister Janez Drnovšek from the Liberal Democratic Party (Liberalno demokratska stranka, LDS). Thirdly, others criticised Jelinčič for the authoritarian style of leadership. Last but not least, it was revealed that Jelinčič had collaborated with the secret police of the former communist regime. ${ }^{3}$ (Rizman 1999, 152)

Internal disagreements led to numerous splits and withdrawals of MPs from the SNS during its first term in the Parliament - in 1996, only three out of 12 MPs stayed in the SNS till the end of the term. In 1993, the SNS split up and a former member of the SNS, Sašo Lap, founded a new political party called the Slovenian National

3 Allegedly he was forced to cooperate with the secret police because of his petty criminal activities including thefts of antiques. (Gorazd Kovačič, interview by Lucie Chládková, January 22, 2014, Thai Inn Pub) Jelinčič was sentenced to three and a half years in prison for a theft in a museum in 1975. (RTV SLO 2007). Moreover, Jelinčič was accused of illegal activities even after 1991 but he has never been convicted. One of the most serious allegations connected to Jelinčič was his possible complicity in an attempted murder for which was Andrej Šiško, leader of the far-right organisation Hervardi, and another associate in crime sentenced to one year and ten months in prison. (Klipšteter 2008) Presumably Jelinčič founded the SNS in order to gain political immunity. 
Right (Slovenska Nacionalna Desnica, SND). (Sotlar 2002, 599) Another breakaway political formation was the National Party of Labour (Nacionalna stranka dela, NSD) which became an insignificant extra-parliamentary political party.

The SNS got into Parliament again in 1996, despite the competition from newly formed political parties such as the SND and the NSD. The SNS stressed its negative attitude towards the Catholic Church, especially rejecting the return of assets to the Church and again being very positive towards the role of partisans during the Second World War. After elections, the SNS negotiated with Janez Drnovšek in order to participate in a government; however, the first proposed composition of the government did not receive enough support in the Parliament, therefore later on Drnovšek decided not to include the SNS into the government. (Krašovec 2012, 279) It is true that the SNS was a parliamentary party with the smallest coalition potential ${ }^{4}$ but it has never been an anti-establishment party. In the past, the SNS supported governments and their propositions as well as initiatives of the opposition as long as the SNS considered them to be "good projects".

In 2000, the SNS won $4.39 \%$ of votes and repeated the result from the previous elections getting four seats in the Parliament. In general, the SNS was very successful in finding electoral niches, i.e. topics that were not represented by other political parties. During general elections in 2000, the SNS concentrated on the issue of Euroscepticism. In 2004, the SNS won six seats and in 2008 five seats in the Parliament. ${ }^{5}$

In January 2008, the SNS experienced another big split. There were two main reasons for the separation. One reason was the disharmony in the parliamentary party group. The second reason was Jelinčič's open support to the government of Janez Janša from the SDS. (Krašovec 2012, 268) Four MPs decided to leave the SNS; however, one MP, Bogdan Barovič, changed his mind in the last moment and stayed in the SNS. Barbara Žgajner Tavš, Boštjan Zagorac and Sašo Peče left the SNS and established a new political party called Linden Tree (Lipa).

In 2010, the SNS was affected by the conviction of Srečko Prijatelj, an MP of the SNS, who was charged and sent to prison because of corruption and blackmail. He was the first MP of the Slovenian Parliament sentenced to prison.

4 For instance, in 2004 the SDS refused to form a coalition government with the SNS, even though the election results were relatively tight and the SNS' ideological affiliation would be more suitable than that of the Democratic Party of Pensioners (Demokratska stranka upokojencev, DeSUS), which became a government party in the end. (Strmiska a kol. 2005, 544).

5 It is worth mentioning that in national elections in 2008, the SNS expected its best result yet because Zmago Jelinčič was very successful in presidential elections in 2007, receiving 19.16 $\%$ of votes and finishing in 4th place. (Electoral Commission 2014). Jelinčič ran for the office of the President of Slovenia first time in 2002 when he received $8.5 \%$ of votes and gained the third best result in the first round. (Trplan 2005, 227). 
In the early elections in 2011, the SNS did not enter Parliament for the first time, receiving only $1.8 \%$ of votes. (Electoral Commission 2014) It is argued that the SNS failed to find the appropriate stance in economic and financial matters, i.e. in topics that dominated the election campaign. The SNS repeated the same failure in early general elections in 2014.

The SNS has not been able to establish itself on the EU level when it did not receive enough votes in each of the elections to the European Parliament.

\section{Programme of the SNS}

From the beginning of the 1990s, the SNS' ideology and rhetoric were clearly nationalist and populist and very similar to other right-wing populist parties such as the National Front from France or the Austrian Freedom Party. (Rizman 1999, 152) The SNS adopted purely nationalistic stance and gradually incorporated related topics such as Euroscepticism or the Roma issue.

The SNS always presented itself as a defender of all Slovenes not serving to narrow political interests. The party perceived itself as the protector of common people that would bring back "Slovenia to Slovenes". Therefore the SNS stood against granting rights or even citizenship to foreigners, especially those coming from the former republics of Yugoslavia. A special category of individuals born in other republics of exYugoslavia constituted the so- called "erased" (izbrisani) who were mostly economic migrants that lost any legal status in newly-born Slovenia after they failed to acquire Slovenian citizenship. The SNS repeatedly refused to remedy the situation of the "erased" and was openly xenophobic towards them. The following subchapter deals with the issue of the "erased" in detail.

Another main aspect of the SNS' programme was irredentism and the SNS was a proponent of the restoration of Great Slovenija (Velika Slovenija) that would encompass Austrian Carinthia, Croatian Istria and the Italian Furlania-Julian region. Jelinčič himself is a defender of the so-called Venetic theory ${ }^{6}$ that places origins of the Slovenian nationhood to ancient times and emphasises the democratic nature of the first homeland of Slovenians, despite the fact that this amateur theory is being rejected by mainstream historians.

This interpretation of past Slovenian greatness influenced the approach of the SNS to foreign policy. The SNS perceived the presence of the Yugoslav People's Army in Slovenia after its independence as a threat to Slovenia and commended possible individual actions of Slovenian citizens to defend their homes. Jelinčič himself took part in the Ten-Day War in June 1991, when Slovenia was gaining independence from Yugoslavia, but not as a member of the regular Slovenian armed forces (Territorial

6 See more in Repe 2012 or Cabada 2005. 
Defence or Police). (Sotlar 2002, 599) According to Jelinčič's CV, he "participated in some brave actions in which he risked his life" and his participation became part of the SNS' identity. (SNS 2007) Therefore the element of violence has always been present in the SNS' programme and rhetoric as this and other statements to instigate violence prove.

The SNS' slogan for the first elections in 1992 was "Make this land Slovenian again" which paraphrased the words of Adolf Hitler that he pronounced in Maribor at the beginning of the Second World War when he said "Make this land German again". (Krašovec 2012, 273) In its first programme, the SNS promised to tackle high unemployment, reduce the number of non-Slovenians living in Slovenia by $90 \%$, abolish the citizenship to all non-Slovenians that gained it after 1990, and to annul the law on citizenship. Jelinčič also openly stated that granting of citizenship to more than $150,000^{7}$ people from ex-Yugoslav republics constituted genocide against Slovenian people. (Rizman 1999, 152)

In economic policies, the SNS did not see the future of heavy and engineering industry in Slovenia and estimated that shutting down these factories would save $40 \%$ of consumption of electric energy and that it would force workers from other exYugoslav republics to leave and enable young Slovenians to acquire housing and jobs instead of non-Slovenes. (Kuzmanić 1995, 53)

Among other priorities of the SNS was the legalisation of weapons, the access to benefits of the welfare state only to Slovenians and Slovenian citizens, or the right to abortion. The SNS advocated also some left-wing positions such as the separation of the Church and state or the aforementioned positive evaluation of the role of partisans. It is apparent that the SNS developed in their programme suggestions that were definitely appealing to left-wing voters, too.

After the split of the party in 1993, the SNS moderated its rhetoric, left too radical standpoints and became more pragmatic. It is also interesting to mention that before the party's division the SNS had links to the skinhead movement when Jelinčič financially contributed to the production of a skinhead fanzine, Young Home Guard (Mladi domobran). (Trplan 2005, 227) This gesture was, however, in direct opposition to Jelinčič's support of the partisan movement from the Second World War.

Not only is the Slovenian society as a whole divided upon the fascist legacy from the war period, but so is the Slovenian far-right scene. During the Second World War,

7 There were around 200,000 people from the former republics of Yugoslavia living in Slovenia in 1991, when Slovenia gained its independence. Around 170 thousand of them were able to acquire Slovenian citizenship and the rest (25 thousand) were "erased". See more in the subchapter "The "erased" - Slovenia's illustration of nationalism". The numbers of non-Slovenes living in Slovenia are very often subject to propaganda or misinterpretation - in this case the SNS used the number 150 thousand, instead of 170 thousand. 
the Slovenian resistance movement was divided into two blocks - the communist camp represented by communists and its partisans ("red" camp), and the Churchrelated resistance block ("black" camp). Because the communists tried to monopolise the resistance movement, the predominantly rural population established the so-called Home Guard (domobranstvo) to fight against communist partisans. (Černič 2011, 2) Historians or the Slovenian society are still not unified on this issue whether the Home Guard collaborated with the Italian occupation administration or if the events could have been characterised as a civil war. As a result of an agreement between Josif Broz Tito, who represented the whole communist resistance movement in Yugoslavia, and the monarchist exile government, the Home Guard was supposed to cease fights against communists which they refused. (Cabada 2005, 59-60) After the end of the Second World War, members of the Home Guard tried to escape to Austria but were returned by the British military back to Slovenia. Subsequently, communists massacred approximately 10,000 members of the Home Guard as a part of the post-war extrajudicial killings. (Cabada 2005; Hančič et al. 2010)

Jelinčič's position towards the previous communist regime was therefore at least ambiguous - on the one hand, Jelinčič rejected Yugoslavia and proposed nationalism and, on the other hand, he was acknowledged the positive role of partisans and actually collaborated with the communist secret police.

In the end of the 1990s, the SNS concentrated even more on the Roma issue. The SNS many times strived for abolishment of the status of Roma people as a minority in Slovenia and even tried to change the Constitution so that the Roma community would not have any special rights. (Trplan 2005, 228) Many times during his political career, Jelinčič showed disrespect to minorities, including the Roma, by using derogatory terms such as "nigger" or "Gypsies (cigani)" when referring to members of different minorities. (Trplan 2005, 227) Jelinčič also faced a criminal trial for promoting hatred and intolerance when he was repeatedly using the word "Gypsy" on a TV show in 2006 but the court decided in his favour. (Felc 2011)

As mentioned earlier, the SNS throughout its mandates in the Parliament changed its rhetoric and became more moderate. The shift is confirmed by sociologist Gorazd Kovačič when Jelinčič started attacking Roma or non-Slovenians not on the basis of their ethnicity but of their life style - he started to differentiate between those who were employed and paid credits, and those who stole or did not work. (Gorazd Kovačič, interview by Lucie Chládková, January 22, 2014, Thai Inn Pub) ${ }^{8}$

During the 2000s, the SNS included other topics in their programme such as the Euroscepticism (the SNS opposed the membership of Slovenia in the EU and NATO

8 The abovementioned interview was conducted as part of research for the master's thesis "The Far Right in Slovenia" by Lucie Chládková. The transcript of an audio recording is in the possession of the author. 
as well) or the Muslim issue picking up on the trend of linking Muslims ${ }^{9}$ with terrorists. (Markotisch 2008, 187) The SNS was also propositioning a referendum about the accession of Croatia to the EU or NATO because of the mutual border dispute.

To illustrate Jelinčič's political ambiguity, after the NATO bombing of Kosovo in 1999, Jelinčič started to build better relations with Serbia and heavily criticised the bombing itself. (Žerdin 2005) This Jelinčič’s political shift could be explained as an opportunity to strengthen the ties with Belgrade in order to have leverage over Zagreb in their mutual disputes. Nevertheless, this Jelinčičs's move does not comply with the early nationalism of the SNS and refusal of immigrants coming from the former republics of Yugoslavia, especially from Serbia.

The SNS and its leader did not abstain from radical statements even in the new millennium as Jelinčič's comment about paedophiles made on TV Paprika in 2006 clearly shows: "[...] I would also burn on paedophiles one big letter P on their heads with glowing iron, in order to know who he is, so that parents shy away from this man [...]". (Varuh človekovih pravic 2006) ${ }^{10}$

The updated programme of the SNS from 2008 also includes environmental topics as well as the "law and order" section. (SNS 2014a) The latest programme of the SNS for recent national elections in 2014 highlights mainly points concerning economic and social security issues or the "abolition of police, judicial or tax oppression". (SNS 2014b)

\section{The "erased" - Slovenia's illustration of nationalism}

When Slovenia became an independent state in 1991, it also had to adopt new legal rules concerning citizenship. New provisions stated that citizens from other former republics of Yugoslavia with permanent residence in Slovenia had to apply for Slovenian citizenship within 6 months from the date of independence. There were around 200 thousand people from other republics of the former Yugoslavia living and working in Slovenia at that time. Approximately 25,000 of them failed to acquire Slovenian citizenship and consequently were "erased" from the register of permanent residents and lost any legal status in Slovenia, thus losing social and economic rights. On a practical level, the "erased" lost their jobs, were evicted from their apartments,

9 In 1992, Zmago Jelinčič was also allegedly engaged in a shooting against a group of Muslims because he did not like they were speaking in their own language. (Sotlar 2002, 599) According to Jelinčič, they attacked him so his behaviour was just self-defence. (RTV SLO 2007).

10 Translation from Jelinčič's original statement: "[...] jaz bi pedofilom tudi užgal $v$ glavo eno tako veliko črko P z žarečim železom, da bi se vedelo, kdo je, da bi se starši izogibali tega člověka [...]". (Translation done by the authors of this paper). 
lost their pensions, were refused medical care, or could not leave or re-enter Slovenia.

The Slovenian Constitutional Court ruled that the erasure was unconstitutional and instructed state authorities to remedy the status of the "erased"; however, it was not until the European Court of Human Rights confirmed the violation of rights of the "erased" and ordered Slovenia to establish a compensation mechanism for the "erased" that entered into force in 2013. (Vučko 2013, 10) The erasure represents the major human rights violation in the modern Slovene history.

The reluctance of Slovenian political elites to solve the status of erased people could be explained by various reasons but mainly by the then nationalism in Slovenia during the 1990s when Slovenia formed an independent state for the first time in its history. Xenophobic sentiments towards the citizens of the former republics of Yugoslavia were caused by a complicated separation of Slovenia from the rest of Yugoslavia, by the often problematic coexistence within the Yugoslav Federation as such and by consequences of the Yugoslav wars such as a huge influx of refugees from the Balkans (around 70,000 refugees between 1992 and 1995 came to Slovenia). (Sotlar 2002, 595) Some political parties (including the SDS) stressed the idea that many of the "erased" were former members of the Yugoslav People's Army, therefore many of them actively participated in the aggression against Slovenia. (Čuček 2006)

The negative stance of mainly the right-wing political parties could be explained not only by the animosity towards the Balkans and their interpretation of the "erased" as a threat to Slovenia's independence, but also by the rivalry of the right-wing and left-wing political circles. One of the reasons, which many political parties repeated in order to refuse to grant permanent residence to the "erased", was the fear that the "erased" would demand compensations from the state for Slovenia's maltreatment of them.

Among the most audible critics of any remedy mechanisms for the "erased" were the SNS, the SDS and other minor mainly right-wing political parties. Right from the start, the SNS started to target the "erased" labelling them as a threat to Slovenian sovereignty and independence. (Markotisch 2008, 187) The SNS regularly opposed amendments to the law on citizenship that were supposed to remedy the situation of the "erased". The SNS also proposed to take away the Slovenian citizenship from nonSlovenes who had already acquired it.

The SNS and its leader Zmago Jelinčič were infamous for racist and xenophobic statements directed towards the "erased". For instance, in 2003 Jelinčič expressed his opinion on the "erased" by stating that "[...] democratic Europe would throw those people on trucks, train wagons or planes and send them back to their home countries ". ${ }^{11}$ Allegedly Zmago Jelinčič and members of the SNS did not use only verbal

11 Jelinčič made this statement during the TV show Trenja on 6 March 2003. The Association of Erased Residents filed a criminal complaint against Jelinčič which was later on dismissed 
racist attacks, but they also tried to ignite violence against the "erased" in Slovenia. In 2005, Sašo Peče supposedly hung up a flyer on the doors of the office of the SNS in the Parliament that stated: "All Erased invited to the dance! Music will be played by Jelinčič on a machine gun!!!”. (Gregorčič 2008, 123) This incident happened during the visit of the "erased" in the Parliament. Later on Peče refused these allegations and blamed the media, the "erased" and activists for this flyer.

There were also many initiatives to vote on the status of the "erased" in referendums. The most serious attempt was made in 2004, when the SDS along with other opposition parties (including the SNS) called for a referendum on the "technicalities bill" that was supposed to remedy the status of the "erased". (Amnesty International 2005, 9) 95\% of those who voted (only $31 \%$ of eligible voters came) were against the bill that would restore rights of the "erased"; however, the Constitutional Court delivered judgement that the result of the referendum was legally irrelevant given the fact that the "core" part (the systemic bill) was not and could not be a question for a referendum.

Currently, the SNS is mostly concerned about the compensation scheme for the "erased" and the party fears that the mechanism might be a target of different sorts of speculators. (Delo 2014)

\section{Members and Electoral Base of the SNS}

There are several common characteristics that the electorate of the SNS shares. Voters of the SNS identify themselves rather as more left-oriented than right-oriented. (Klavora 2009) The SNS has the youngest supporters $-60 \%$ of their voters are younger than 45 years, and, for instance, around 34\% of their voters are less than 30 years old. More than $70 \%$ of its electorate is represented by men. In average, more than $40 \%$ of voters of the SNS are religious. The SNS has the smallest share of voters with a higher or university education among the parliamentary parties.

The support of the SNS is not territorially determined. (Kleinová 2007, 62) From the elections in 1996 onwards, the SNS does not have steady outstanding support of voters in any of election districts. The SNS receives the best election results in election districts in Maribor and Celje. In contrast, the SNS is gradually losing support in election districts of Ljubljana-Bežigrad and Ljubljana-Centre.

The local network of the SNS is actually the weakest among other parliamentary parties. Since municipal elections in 1994, the SNS has had its candidates in fewer than a half of all municipalities and less than $20 \%$ of their candidates were elected. (Krašovec 2012, 277)

The SNS has around 7,000 members according to its website. (SNS 2014a) It is noteworthy that the SNS established a special commission that chooses future party

by the public prosecutor. (Gregorčič 2008, 233-234). 
members who should be ethnic Slovenes. This selection mechanism indicates the elitist and exclusive nature of the party. (Kuzmanić 1995, 51)

\section{The SNS and its relation to the extreme-right scene in Slovenia and abroad}

The SNS was an incubator for other far-right political parties that were not, however, as successful as the SNS in parliamentary elections and rather caused disunity of the far-right political scene when they competed with the SNS. Following political parties have always been extra-parliamentary parties, except for the time when new split-up parties from the SNS were created and the MPs of newly formed parties stayed and operated in the Parliament. Throughout the time, the SNS was profiteering rather from cooperation with social-democratic and liberal parties on the left side of the political spectrum than from cooperation with right-wing parties. (Hloušek 2002, 385)

The Slovenian National Right (SND), which was formed in 1993 by a former MP of the SNS, has never been able to attract enough votes to re-enter the Parliament, therefore its influence gradually deteriorated. The SND was much more radical than the SNS using slogans such as "Let's make this country Slovenian again" or "Slovene will be master on his own land". (Trplan 2005, 228) The SND was infamous for establishing an organisation called Slovenian Falcons (Slovenski Sokoli) which was the first and till today the only paramilitary organisation in Slovenia with a protective and intelligence role. (Krašovec 2012, 269) Members of the Slovenian Falcons wore uniforms but were unarmed and their task was to fight against non-Slovenes, especially the Serbs if necessary.

The SND went through a process of transformation and now its successor is the Party of the Slovenian People (Stranka slovenskega naroda, SSN). The SSN also teamed up with Andrej Šiško from the Association Hervardi ${ }^{12}$ who ran for the SSN in the national elections in 2008.

Another split-party from the SNS was the National Party of Labour (Nacionalna stranka dela, NSD) that had ties with the Slovenian division of Blood and Honour when five followers of this neo-Nazi group ran for the NSD in local elections. (Ozmec 2002) Despite the fact that the NSD is an extra-parliamentary party, its leader Marjan Polšjak was able to establish himself on a local level when he was elected mayor of the town of Ajdovščina in 2000 and was re-elected into this position for another three consecutive times. (Ajdovščina 2014)

12 Hervardi is a formally registered organisation that was founded on 1 May 2004 (as a sign of protest against Slovenia's entry to the European Union) and its aim is to preserve Slovenian patriotic traditions and to protect Slovenian identity. In reality, their actions and statements publicised on their website are nationalistic, racist and xenophobic. Hervardi also once tried to establish viable relations with the Slovenian division of Blood and Honour. 
In 2008, rebellious MPs from the SNS formed a political party Linden Tree (Lipa) that soon disappeared from higher spheres of the Slovenian political arena. Lipa used as its emblem the leaf of a linden tree as a traditional symbol popular with the Slovenians. Actually the party's political programme did not differ from the programme of the SNS very much; however, internal disagreements within the SNS led some MPs of the SNS to form a splinter political party. Lipa blamed the SNS for supporting the centre-right government led by the SDS, which they considered to be corrupt, and disagreed with Jelinčič's authoritarian style of leadership.

The SNS also engaged in conflicts with other far-right and populist political parties which were not breakaway parties of the SNS. Such were the Republicans of Slovenia (Republikanci Slovenije, RS) who during the 1990s advocated stricter measures against ethnic non-Slovenes who should not have had any special status or hold public functions, but the party drifted away from public attention years ago. (Trplan 2005, 229)

The National Social Union of Slovenia (Nacional-socialna zveza Slovenije, NSZS) did not have friendly relations with the SNS either. The NSZS was the only political party in Slovenia that was denied official registration on the basis of their political programme which was not in accordance with the Constitution of Slovenia. (Trplan $2005,230)$ The party was concerned about the safety and well-being of ethnic Slovenes and therefore the NSZS established the so-called troikas (trojke) which were groups of three men, presumably unarmed, that were supposed to protect "common Slovenes" from "Southerners". (Rizman 1999, 157) A few such groups appeared in Maribor patrolling the streets, but they were very soon banned by the Ministry of the Interior.

The SNS has never been able to establish warm relations with the rest of the farright scene in Slovenia given the fact that basically all far-right organisations share anti-communist stance, which is a typical trademark of the far right in post-communist countries. On the other hand, the SNS has always supported the fight of communist partisans during the Second World War.

The SNS was also not able to form meaningful relationships with similar political parties on the European or international levels. The only exception was the visit of Vladimir Zhirinovsky to Slovenia. The potential second visit by Zhirinovsky was banned by the Slovenian government. (Rizman 1999, 152) In the Balkan region, the SNS communicated only with the right-wing Croatian Party of Rights (Hrvatska stranka prava, HSP), specifically with its then leader Dobroslav Paraga who surprisingly agreed on the status of Istria with the SNS. Paraga stated that Istria had never been part of Croatia because Croatia had got Istria in exchange for territories which had been given to Bosnia and Herzegovina. (Kuzmanić 1995, 55) 


\section{Conclusion}

In its politics, the SNS has thematised strong Slovenian nationalism, rooted in historical legacies and aimed against "the others." However, irredentist demands or discrimination of "erased people" are no more important topics of Slovenian policy as they were in previous decades. Slovenia faces many problems such as corruption, economic crisis, and so on, and the SNS lost the position of an "accepted alternative" for many former voters. The party was never part of the governmental coalition and it can use the "anti-establishing" propaganda in its politics. However, after twenty years of its existence, the party stagnated. It has been isolated not only in the Slovenian political spectrum as a whole, but also in the domestic and international extreme right spectrum.

The answer to our first research question is possible with the use of several criteria elaborated by Uwe Backes. The general opportunity structure was caused due to strong nationalist environment during the transformation era (including sensitivity of the "erased" issue) and non-existence of the left radical competitor. The SNS was able to offer an attractive programme within this framework and a charismatic leader. However, the campaigns of the party were not able to mobilise a stabile electorate.

The decline of the party - related to the second question - was connected with other factors. The use of cordon sanitaire and competition of strong centre parties caused the isolation of the SNS. The real capability to have impact on Slovenian politics was limited and this situation can be considered as a key element - this party has won the image of an "unsuccessful player" after more than 15 years in opposition. The decline of the SNS started when the "erased" issue lost its importance and when a new populist alternative grew up in the Slovanian party system. Repressive measures of militant democracy and strong counter-mobilisation did not occur and they were not necessary.

The answer to the third question depends on a possible future rise of the opportunity structure. The development of the Slovenian party system is still very dynamic and nationalism plays an important role. New fringes of Eurosceptism or Islamophobia can be observed (Mareš 2014). However, the SNS has probably a very limited chance to win its lost positions. New forms of nationalist parties and movements can be expected in Slovenian politics.

\section{References}

AJDOVŠČINA. „Življenjepis in politična usmeritev”. In: Ajdovščina [online], 2014 [cit. 201502-13], Dostupné na: http://www.ajdovscina.si/organi_obcine/zupan/2012083109174667/. AMNESTY INTERNATIONAL: „Slovenia: The ,erased“ - Briefing to the UN Committee on Economic, Social and Cultural Rights". In: Amnesty International [online], 2014 [cit. 201409-28], Dostupné na: http://www.amnesty.org/en/library/info/EUR68/002/2005/en. 
BACKES, U.: The Unsuccesfull Parties. Ideologies, Strategies, and Conditions of the Failure. In Backes, U. - Moreau, P. (ed.): The Extreme Right in Europe. Current Trends and Perspectives. Göttingen, Vandenhoeck \& Ruprecht, 2012, s. 49-169.

BAJT, V.: Myths of Nationhood. Slovenians, Caranthania and the Venetic Theory. Annales, roč. 21, č. 2. 2011, s. 249-260.

BAYER, J.: Rechtspopulismus und Rechtsextremismus in Ostmitteleuropa. Österreichischer Zeitrschrift für Politikwissenschaft, roč. 31, č. 3, 2002, s. 265-280.

BREZOVŠEK, M. - HAČEK, M. - ZVER, M.: Democratic Praxis in Slovenia. Plzeň: Vydavatelství a nakladatelství Aleš Čeněk, 2007. ISBN: 978-80-7380-016-1.

CABADA, L.: Politický systém Slovinska. Praha: Sociologické nakladatelství Slon, 2005.

CHLÁDKOVÁ, L. : The Far Right in Slovenia (Master's thesis). Brno: Faculty of Social Studies of the Masaryk University, 2014.

ČERNIČ, J. L.: „Responding to crimes against humanity committed in Slovenia after the Second World War". In Oxford Transitional Justice Research - Research Article 4 [online], 2011, s. 1-13 [cit. 2014-09-28]. Dostupné na: http://otjr.crim.ox.ac.uk/materials/papers/176/ OTJRRP4Cernic.pdf.

ČUČEK, T.: Slovenski poslanci o izbrisanih: analiza parlamentarnih razprav. In Kuhar, R. Autor, S. (ed.): Poročilo skupine za spremljanje nestrpnosti. Ljubljana, Mirovni Inštitut, 2006, s. 190-211.

DELO: „Je prav, da za izbris ni nihče odgovarjal?”. In: Delo [online], 2014, [cit. 2014-09-21], Dostupné na: http://www.delo.si/novice/volitve/je-prav-da-za-izbris-ni-nihce-odgovarjal. html.

ELECTORAL COMMISION: „Arhiv volitev v Državni zbor RS”. [online], 2014, [cit. 201409-21], Dostupné na: http://www.dvk-rs.si/index.php/si/arhiv-drzavni-zbor-rs.

FELC, M.: „Gostje v sporni oddaji Piramide so bili po svoje tudi izzvani, meni sodnica”. In: Delo [online], 2011 [cit. 2014-09-21], Dostupné na: http:/www.delo.si/clanek/136412.

GREGORIČ, M.: „Phantom Irresponsibility, or Fascism in Disguise”. In: Journal for the Critique of Science, Imagination, and New Anthropology [online], roč. 35, č. 228, 2008, s. 115-132 [cit. 2014-09-28]. Dostupné na: http://www.mirovni-institut.si/izbrisani/wpcontent/uploads/2012/02/CKZ journal on the erased 2008.pdf.

HANČIČ, D. - KOLARIČ, B. - С̆CRNIČ, J. L. - PODBERSIČ, R. - VALIČ, A.: „National Report of the Crimes of Communism in Slovenia" [online]. Ljubljana: Study Centre for National Reconciliation, Slovenia, 2010 [cit. 2014-09-28], Dostupné na: http:/www.ustrcr. cz/data/pdf/konference/zlociny-komunismu/COUNTRY\%20REPORT\%20SLOVENIA. pdf.

HLOUŠEK, V.: Republika Slovinsko. In Fiala, P. - Holzer, J. - Strmiska, M. (ed.): Politické strany ve střední a východní Evropě: ideově-politický profil, pozice a role politických stran v postkomunistických zemích. Brno: Masarykova univerzita, 2002, s. 382-399.

JESSE, E. - THIEME, T.: Extremismus in den EU-Staaten im Vergleich. In: Extremismus in den EU-Staaten, edited by Jesse, Eckhard, and Thieme, Tom (ed.): Wiesbaden, VS Verlag für Sozialwissenschfaten, 2011, s. 431-482.

KLAVORA, J.: „Dejavniki sprememb volilnega vedenja v Sloveniji v obdobju 2004-2008“. MA thesis [online]. Ljubljana, Fakulteta za družbene vede, 2009 [cit. 2014-09-28]. Dostupné 
na: http://dk.fdv.uni-lj.si/diplomska/pdfs/klavora-jan.pdf.

KLEINOVÁ, L.: Analýza výsledků parlamentních voleb v Republice Slovinsko a jejich dopad na stranický systém na celostátní a teritoriální úrovni. MA thesis. Masarykova univerzita, Brno, 2007.

KLIPŠTETER, T.: „Andrej Šiško s predvolilnega soočenja v zapor“ [online]. In Dnevnik,2008, [cit. 2014-09-21], Dostupné na: http://www.dnevnik.si/kronika/1042204070.

KRANJC, G. J.: To Walk with the Devil: Slovene Collaboration and Axis Occupation, 19411945. Toronto, University of Toronto Press, 2013.

KRAŠOVEC, A.: Slovenia. In: Havlík, V. - Pinková, A. (ed.): Populist Political Parties in EastCentral Europe. Brno: Masaryk University, 2012, s. 259-284.

KUZMANIČ, T.: Politični ekstremisem pod Slovenci: SNS od tigrov do papirja. Časopis za kritiko znanosti, domišljijo in novo antropologijo, roč. č. 176, 1995, s. 47-70.

LUTHAR, O. - LUTHER, B.: Von der Ideologie zur Mythlogie? Historischer Revisionismus im postsozialistischen Slowenien. In Flierl, T. - Müller, E. (ed.): Osteuropa - Schlachtfeld der Erinnerungen. Berlin: Karl Dietz Verlag, 2010, s. 105-129.

MAREŠ, M.: Extremismus in Slowenien. In: Jesse, E. - Thieme, T. (ed.): Extremismus in den EU-Staaten. Wiesbaden, VS Verlag für Sozialwissenschaften, 2011, s. 361-375.

MAREŠ, M.: Islam in East Central European Politics: A New Challenge for Democracy? Conference Paper, 19th Annual Conference of Central European Political Science Association: Liberal or Other Democracy? 25 Years after the Annus Mirabilis in Central Europe, 2014.

MARKOTICH, S.: South Eastern Europe and the Far Right. In Davies, P. - Jackson, P. (ed): The far right in Europe: an encyclopaedia. Oxford, Westport, Greenwood World Press, 2008, s. 165-192.

OZMEC, S.: „Skinheadi v slovenski politiki”. In: Mladina [online], 2002 [cit. 2014-09-28], Dostupné na: http://www.mladina.si/88626/m-skini2/?utm_source=tednik\%2F200250\%2 Fclanek\%2Fm-skini2\%2F\&utm_medium=web\&utm_campaign=oldLink.

REPE, B.: „Slovenes and their Identity after the Disintegration of Yugoslavia”. Lecture Held at the Faculty of Arts of Charles University in Prague [online], 2012 [cit. 2014-09-26], Dostupné na: http://wffl.ff.uni-lj.si/oddelki/zgodovin/wwwrepe/Microsoft\%20Word\%20 -\%20Slovenci\%20in\%20njihova\%20identiteta\%20po\%20razpadu\%20Jugoslavije\%20 -\%20Praga ANG.pdf.

RIZMAN, R. M.: Radical Right Politics in Slovenia. In: Ramet, S. (ed.): The Radical Right in Central and Eastern Europe since 1989. Pennsylvania: The Pennsylvania State University Press, 1999, 147-170.

RTV SLO: „V središču sumljivih in provokativnih dogodkov”. In: RTV SLO [online], 2007 [cit. 2014-09-28], Dostupné na http://www.rtvslo.si/predsedniske-volitve/v-srediscu-sumljivihin-provokativnih-dogodkov/77571.

SMEJKALOVÁ, T.: Slovenian Minority in Austria. The Annual of Language \& Politics and Politics of Identity, roč. 1, č. 1, 2007, s. 35-42.

SNS. „Življenjepis”. In: SNS [online], 2007 [cit. 2014-09-21], Dostupné na http://www.sns.si/ zmago/zjp/biografija/.

SNS. „Slovenska nacionalna stranka”. In: SNS [online], 2014a [cit. 2014-09-28], Dostupné na 
http://www.sns.si/stranka/.

SNS.. "Aktualizirana programska izhodišča Slovenske nacionalne stranke pred volitvami v

Državni zbor Republike Slovenije 2014.” In: SNS [online], 2014b, [cit. 2014-09-21], http:// www.sns.si/.

SOTLAR, A.: Coping with extremism within society - the Slovenian experiences. In: Pagon, M. (ed.): Policing in Central and Eastern Europe: Deviance, Violence, and Victimization. Ljubljana, College of Police and Security Studies, 2002, s. 593-610.

STRMISKA, M. - HLOUŠEK, V. - KOPEČEK, L. - CHYTILEK, R.: Politické strany moderní Evropy: analýza stranicko-politických systémů. Praha: Portál, 2005. ISBN: 80 7367-038-0.

TRPLAN, T.: Slovenia. In: Mudde, C. (ed.): Racist Extremism in Central and Eastern Europe. London, Routledge, 2005, s. 225-246.

VARUH ČLOVEKOVIH PRAVIC: „Novinarska konferenca”. In: Varuh človekovih pravic [online], 2006 [cit. 2014-09-21], Dostupné na: http://www.varuh-rs.si/medijsko-sredisce/ novinarske-konference/leto-2006/2822006/.

VUČKO, K.: „The Erased: Slovenia’s Most Severe Human Rights Violation”. In: Begant, E. (ed.): DARE Srping Academy 2013. Innovative Approaches in HRE/EDC to Overcome Discrimination of Vulnerable Groups in Europe [online]. Maribor, Democracy and Human Rights Education in Europe Network, 2013, s. 7-12 [cit. 2014-09-27], Dostupné na: http://www.dare-network.eu/downloads/DARE_Innovative_Approaches_to_Overcome Discrimination_of_Vulnerable_Groups_in_Europe.pdf.

ZORN, J.: A case for Slovene nationalism: initial citizenship rules and the erasure. Nations and Nationalism, roč. 15, č. 2, 2009, s. 280-298.

ŽERDIN, A. H.: „Peto kolo ali peta kolona.” In: Mladina [online], 2005, [cit. 2014-09-28], Dostupné na: http://www.mladina.si/92534/peto-kolo-ali-peta-kolona/.

Prof. JUDr. PhDr. Miroslav Mareš, PhD. (1974), Director of the study programme Security and Strategic Studies. He focuses on research in extremism and terrorism in Central Europe. He is the author or co-author of many publications, i.a. he has written (with Astrid Bötticher) the book Extremismus - Theorien - Konzepte - Formen (München, Oldenbourg Verlag 2012).

Mgr. Lucie Chládková (1988), studied Security and Strategic Studies at the Faculty of Social Studies of Masaryk University and in 2014 she defended her Master's thesis "The Far Right in Slovenia". She cooperates with Masaryk University and focuses on research in migration and far right in Europe. 
Prof. JUDr. PhDr. Miroslav Mareš, PhD. (1974),

Department of Political Science, Faculty of Social Studies, Masaryk University, Jostova 10, 602 00, Brno, Czech Republic (mmares@fss.muni.cz).

Mgr. Lucie Chládková (1988) Ministry of Interior of the Czech Republic, Nad Štolou 3, P. O. BOX 21, Praha 7, 170 34, Czech Republic (chladkova.lucie@seznam.cz). 